\title{
Annual Parasite Incidence Malaria di Kabupaten Banyumas
}

\author{
Annual Parasite Incidence Malaria in Banyumas
}

\author{
Dwi Sarwani Sri Rejeki*, Ruthi Armita Sari*, Nunung Nurhayati**
}

\begin{abstract}
*Fakultas Ilmu-ilmu Kesehatan Universitas Jenderal Soedirman, **Fakultas Matematika dan Ilmu Pengetahuan Alam Universitas Jenderal Soedirman
\end{abstract}

\begin{abstract}
Abstrak
Kabupaten Banyumas merupakan kabupaten endemis malaria di Provinsi Jawa Tengah. Data Dinas Kesehatan Kabupaten Banyumas tahun 2008 2013 menunjukkan angka annual paracite incidence (API) yang selalu mengalami fluktuasi. Dari 27 kecamatan, 22 di antaranya termasuk dalam kategori medium case incidence $(\mathrm{MCl})$ dan low case incidence ( $\mathrm{LCl}$ ). Faktor lingkungan, perilaku, sosial ekonomi, dan iklim berdampak pada tinggi rendahnya kejadian malaria. Tujuan penelitian adalah mengetahui faktor yang berhubungan dengan API di Kabupaten Banyumas. Data dikumpulkan dari Januari 2011 - Desember 2013 menggunakan penelitian analitik dengan rancangan penelitian potong lintang dan menggunakan data sekunder dari Dinas Kesehatan, Dinas Pertanian, dan Badan Pusat Statistik Kabupaten Banyumas. Populasi adalah seluruh kecamatan di Kabupaten Banyumas dan sampel diambil menggunakan teknik total sampling, sebanyak 27 kecamatan dengan pengamatan selama 3 tahun menjadi 81 sampel. Hasil penelitian menunjukkan $44,4 \%$ pengamatan termasuk kategori LCl dan $\mathrm{MCl}, 48,1 \%$ termasuk kategori curah hujan tinggi, 49,4\% termasuk kategori wilayah yang luas, 49,4\% termasuk kategori jumlah pendatang tinggi, $48,1 \%$ termasuk kategori kepadatan penduduk sedang. Sementara itu, dari 27 kecamatan, yang termasuk ketinggian rendah adalah 63,0\%. Faktor yang terbukti berhubungan dengan API adalah luas wilayah, jumlah pendatang, kepadatan penduduk, sedangkan yang tidak berhubungan adalah curah hujan dan ketinggian.

Kata kunci: Annual parasite insidence, jumlah pendatang, kepadatan penduduk, luas wilayah,malaria
\end{abstract}

\section{Abstract}

Banyumas is malaria endemic district in Central Java. Banyumas Health Office data of 2008 - 2013 showed that, the Annual Parasite Incidence (API) always fluctuated. From 27 subdistricts in Banyumas, there are 22 subdistricts which fall into the category of middle case incidence $(\mathrm{MCl})$ and low case incidence $(\mathrm{LCl})$. Malaria is a disease that closely associated with the enviroment, behaviour, social economy, and climate. The purpose of this study was to determine factors associated with API in Banyumas. Data were collected from Januari 2011 - Desember 2011 using an analytic crosssectional design using secondary data from Banyumas Health Office, Agriculture Office and Statistic Center. The population in this study were all subdistricts in Banyumas and samples were taken using total sampling technique. The sample of this study was 27 districts. The results showed that from 81 samples we obtained $44.4 \%$ of observations included in $\mathrm{LCl}$ and $\mathrm{MCl}$ category, $48.1 \%$ with high rainfall, $49.4 \%$ with large areas, $49.4 \%$ with high number of entrants, $48.1 \%$ with medium population density. Meanwhile, from 27 districts, $63.0 \%$ included in low altitude category. Factors associated with API in Banyumas were the extensive areas, the number of entrants, and population density. The factors that are not associated to the API were the rainfall and altitude regions.

Keyword: Annual parasite insidence, the number of entrants, population density, area, malaria

\section{Pendahuluan}

Malaria merupakan salah satu penyakit menular yang menjadi target untuk dieliminasi secara bertahap sampai tahun 2030. Pada tahun 2012 di seluruh dunia, diperkirakan 207 juta kasus malaria sebagian besar kasus (80\%) terjadi di Afrika, diikuti Asia Tenggara (13\%) dan Mediterania Timur (6\%). Menurut Laporan Riset Kesehatan Dasar (Riskesdas) tahun 2013,1 insiden malaria di Indonesia tahun 2013 adalah 1,9\%, menurun dibanding tahun 2007 (2,9\%). Namun, masih ada beberapa provinsi dengan annual parasite insidence (API)

Korespondensi: Dwi Sarwani Sri Rejeki, Fakultas Ilmu-ilmu Kesehatan Universitas Jenderal Soedirman, Kampus Karangwangkal, Jl. Dr. Suparno Purwokerto 53122, No.Telp: 0281-641202,e-mail: dwisarwanisr@yahoo.com 
yang tinggi sehingga potensi terjadi penularan dan kejadian luar biasa (KLB) bisa terjadi. Data menunjukkan, sebanyak 17 dari 33 provinsi yang memiliki nilai API $<1$ per 1000 penduduk. Selanjutnya, 10 provinsi lainnya memiliki nilai API di antara 1-5 per 1000 penduduk. Sementara 6 provinsi lainnya, memiliki nilai API $>5$ per 1000 penduduk, bahkan ada provinsi yang memiliki nilai API > 50 per 1000 penduduk.

Belakangan ini malaria merupakan salah satu penyakit yang kembali muncul (reemerging desease). Munculnya kembali malaria diduga berkaitan dengan pemanasan global sehingga mengakibatkan penyebaran penyakit parasitik yang ditularkan melalui nyamuk semakin mengganas. ${ }^{2}$ Faktor klimatologi merupakan faktor yang penting dalam penularan malaria. Perubahan cuaca seperti suhu, curah hujan, dan kelembaban mempunyai pengaruh pada populasi Anopheles dan insiden malaria. ${ }^{3,4}$ Hasil penelitian yang dilakukan oleh Paaijmans et $a l,{ }^{5}$ memperoleh perubahan suhu berpengaruh dalam peningkatan pertumbuhan larva. Curah hujan yang tinggi juga akan meningkatkan kelembaban dan memperpanjang usia nyamuk dewasa. Contohnya di Sub-Sahara, penularan malaria lebih banyak pada saat musim hujan. ${ }^{6}$ Peningkatan curah hujan dan kelembaban berbanding lurus dengan kepadatan nyamuk Anopheles. Ketika curah hujan tinggi, kasus malaria lebih banyak yang dilaporkan. ${ }^{7}$ Faktor lingkungan umumnya sangat dominan sebagai penentu kejadian malaria. Nyamuk dapat berkembang biak dengan baik bila keadaan lingkungannya mendukung.

Keberadaan manusia dan nyamuk pada suatu ekologi memungkinkan untuk terjadinya transmisi malaria setempat (indegeneous), sedangkan mobilitas penduduk menurut penelitian Pinsent et $a l,{ }^{8}$ mempunyai risiko lebih besar untuk terjadinya malaria. Berdasarkan penelitian yang dilakukan oleh Ricota et al, ${ }^{9}$ didapatkan hasil bahwa keberadaan vegetasi di sekitar pemukiman berperan dalam memengaruhi perilaku nyamuk, kebiasaan mencari makan, dan akan berpengaruh pula pada kejadian malaria berikutnya.

Jawa Tengah merupakan provinsi dengan jumlah kasus malaria pada tahun 2012 mencapai 2.420 kasus, dengan API sebesar 0,08. Jawa Tengah memiliki lima kabupaten endemis malaria salah satunya adalah Kabupaten Banyumas. Kabupaten Banyumas merupakan daerah yang selalu memiliki kasus malaria, dengan jumlah yang mengalami fluktuasi setiap tahunnya hingga tahun 2013. Dari 27 kecamatan di Kabupaten Banyumas, 22 di antaranya termasuk dalam kategori middle case incidence (MCI) dan low case incidence (LCI). Kabupaten Banyumas merupakan daerah dengan iklim tropis basah dan dengan topografi yang bervariasi dari dataran tinggi, rendah, dan perbukitan. Banyumas merupakan salah satu dari lima kabupaten/kota di Jawa Tengah dengan tingkat kepadatan penduduk yang tinggi. ${ }^{10}$ Banyumas juga memiliki angka migrasi neto positif, yang artinya jumlah penduduk yang masuk lebih banyak daripada yang keluar. ${ }^{11}$ Berdasarkan data tersebut dan hasil penelitian sebelumnya, peneliti tertarik untuk melakukan penelitian terkait faktor yang berhubungan dengan API malaria di Kabupaten Banyumas.

\section{Metode}

Penelitian ini merupakan studi epidemiologi analitik, dengan rancangan penelitian potong lintang dan menggunakan data sekunder. Data sekunder yang digunakan adalah data Kabupaten Banyumas Januari 2011 Desember 2013, meliputi data API, curah hujan, luas wilayah, jumlah pendatang, dan kepadatan penduduk. Sedangkan, untuk data ketinggian diambil pada tahun 2013. Data diperoleh dari berbagai sumber yaitu API dari dinas kesehatan mengenai luas wilayah, dari dinas pertanian mengenai curah hujan, jumlah pendatang, ketinggian, dan mengenai kepadatan dari Badan Pusat Statistik Kabupaten Banyumas. Data API diperoleh dari laporan bulanan malaria puskesmas di Kabupaten Banyumas. Data curah hujan diperoleh dari laporan bulanan 19 stasiun curah hujan di Kabupaten Banyumas. Data luas wilayah diperoleh dari laporan keseluruhan data luas pekarangan, kebun, hutan, dan sawah tiap kecamatan. Data jumlah pendatang diperoleh dari laporan jumlah pendatang yang masuk dalam suatu kecamatan per tahun.

Populasi dalam penelitian ini adalah seluruh kecamatan di Kabupaten Banyumas. Sampel yaitu keseluruhan populasi dengan kriteria inklusi kecamatan dengan data lengkap sesuai yang dibutuhkan. Analisis data secara univariat dan bivariat. Analisis univariat dengan mendeskripsikan setiap variabel sesuai cut off point yang telah ditentukan. Curah hujan dikategorikan tinggi jika $\geq 1500 \mathrm{~mm} /$ tahun, sedang-sangat rendah jika $<1500$ $\mathrm{mm} /$ tahun. Luas tempat perindukan dikategorikan luas jika $\geq 2840$ Ha per kecamatan dan tidak luas jika $<2840$ Ha. Ketinggian dikategorikan sedang jika antara 100-500 mdpl dan rendah jika $<100 \mathrm{mdpl}$. Jumlah pendatang dikategorikan tinggi jika in migrant rate (IMR) $\geq 13,7$ dan rendah jika IMR $<13,7$. Kepadatan penduduk dikategorikan kepadatan tinggi jika $>2000$ jiwa $/ \mathrm{km}^{2}$, kepadatan sedang jika 1000-2000 jiwa/ $/ \mathrm{km}^{2}$ dan kepadatan rendah jika $<1000 \mathrm{jiwa} / \mathrm{km}^{2}$. Data API dikategorikan LCI-MCI dan nonkasus karena pada tahun 2011-2013 tidak ada kecamatan dengan kategori HCI di Kabupaten Banyumas.

Pengategorian data curah hujan, ketinggian, dan kepadatan penduduk didasarkan pada kategori dari Badan Pusat Statistik (BPS). Kategori API didasarkan pada kategori Kementerian Kesehatan Indonesia. Pengategorian luas tempat perindukan dan jumlah pen- 
datang didasarkan pada nilai median. Analisis data menggunakan uji kai kuadrat dengan tingkat kemaknaan 0,05 untuk mengetahui hubungan antara curah hujan, luas tempat perindukan, ketinggian, jumlah pendatang, dan kepadatan penduduk dengan API malaria.

\section{Hasil}

Kabupaten Banyumas berada di bagian selatan barat wilayah Provinsi Jawa Tengah. Kabupaten Banyumas terdiri dari 27 kecamatan, dengan total luas wilayah sebesar 132.738 Ha. Sebanyak 24,32\% dari wilayah Kabupaten Banyumas merupakan lahan sawah serta sisanya $(75,68 \%)$ merupakan lahan pertanian bukan sawah dan lahan bukan pertanian. Lahan pertanian bukan sawah meliputi ladang, kebun, perkebunan, hutan rakyat, perkebunan rakyat, dan lain-lain. Sedangkan lahan bukan pertanian meliputi pemukiman, perumahan, dan lain-lain. Bagian selatan merupakan daerah dataran rendah yang berbukit karena dilewati oleh Perbukitan Serayu, sedangkan dataran tinggi dengan perbukitan terletak di sebelah Utara yaitu di bawah kaki Gunung Slamet.

Kabupaten Banyumas secara klimatologi memiliki iklim tropis basah dengan rata-rata suhu udara $26,3^{\circ} \mathrm{C}$. Suhu minimum mencapai $24,4^{\circ} \mathrm{C}$ dan suhu maksimum berkisar $30,9^{\circ} \mathrm{C}$. Curah hujan di wilayah Kabupaten Banyumas pada tahun 2012 rata-rata mencapai sebesar $1.816 \mathrm{~mm}$ pertahun.

Dari total 27 kecamatan, 22 di antaranya memiliki kasus malaria, walaupun dalam jumlah yang rendah. Hal ini dapat dilihat dari nilai API yang kebanyakan berada dalam kategori LCI. Rendahnya nilai API tetap perlu diwaspadai karena walaupun kecenderungan nilai API rendah, namun kasus malaria ditemukan di sebagian besar kecamatan. Hal ini menunjukkan bahwa sebaran kasus malaria cukup merata pada setiap wilayah di Kabupaten Banyumas.

Data malaria di Kabupaten Banyumas tahun 2009 sampai dengan 2013 menunjukkan bahwa jumlah kasus malaria selalu ada setiap tahunnya (Tabel 1). Kecamatan Kemranjen, Sumpiuh, Tambak, Somagede, dan Kebasen adalah beberapa kecamatan yang selalu menyumbang kasus malaria setiap tahunnya selama lima tahun terakhir.

Hasil penelitian menunjukkan faktor yang terbukti berhubungan dengan API malaria di Kabupaten Banyumas adalah luas wilayah, jumlah pendatang, dan kepadatan penduduk (Tabel 2).

Faktor yang terbukti tidak berhubungan dengan API malaria adalah curah hujan dan ketinggian (Tabel 3).

\section{Pembahasan}

Hasil analisis menunjukkan bahwa ada hubungan antara luas wilayah dengan API malaria. Luas wilayah dalam penelitian ini menggunakan data penggunaan la- han tiap kecamatan meliputi luas kebun, perkebunan, hutan rakyat, dan pekarangan. Hasil penelitian ini sesuai dengan penelitian Alemu et al, ${ }^{6}$ yang menyatakan adanya genangan berkaitan dengan malaria dan penelitian Ernawati dkk, 12 bahwa rumah tangga yang terdapat tempat perindukan nyamuk di sekitarnya memiliki proporsi kejadian infeksi malaria yang lebih besar $(54,5 \%)$ dibandingkan rumah tangga yang di sekitarnya tidak terdapat tempat perindukan nyamuk $(49,4 \%)$. Berdasarkan

Tabel 1. Data API Malaria Per Kecamatan

\begin{tabular}{|c|c|c|c|c|c|}
\hline Kecamatan & 2009 & 2010 & 2011 & 2012 & 2013 \\
\hline Lumbir & $0,05^{*}$ & $0,42^{*}$ & $0,14^{*}$ & $0,18^{*}$ & $0,12^{*}$ \\
\hline Wangon & 0 & 0 & $0,01 *$ & $0,03^{*}$ & 0 \\
\hline Jatilawang & $0,07 *$ & 0 & $0,02 *$ & 0 & 0 \\
\hline Rawalo & 0 & $0,05^{*}$ & $0,04^{*}$ & 0 & 0 \\
\hline Kebasen & $0,12^{*}$ & $0,48^{*}$ & $0,06^{*}$ & $0,13^{*}$ & 0,07 * \\
\hline Kemranjen & $0,11^{*}$ & $1,35^{*}$ & $0,25^{*}$ & $0,09 *$ & 0,03 * \\
\hline Sumpiuh & $1,05^{* * *}$ & $7,78^{* * * *}$ & $3,72^{* * *}$ & $1,07^{* * *}$ & 0,35 * \\
\hline Tambak & $4,57 * *$ & $1,05^{* * *}$ & $2,87^{* * *}$ & $1,47 * *$ & 0,05 * \\
\hline Somagede & $0,09 *$ & $0,46^{*}$ & $0,25^{*}$ & $0,13^{*}$ & 0,03 * \\
\hline Kalibagor & 0 & 0 & $0,04 *$ & 0 & 0 \\
\hline Banyumas & $0,07^{*}$ & 0 & $0,10^{*}$ & $0,75^{*}$ & 0 \\
\hline Patikraja & $0,02^{*}$ & $0,02^{*}$ & 0 & 0 & 0 \\
\hline Ajibarang & 0 & $0,05^{*}$ & 0 & 0 & 0 \\
\hline Gumelar & 0 & 0 & $0,18^{*}$ & $0,04^{*}$ & 0 \\
\hline Cilongok & $0,02^{*}$ & $0,04 *$ & $0,03 *$ & $0,02 *$ & 0,03 * \\
\hline Karanglewas & 0 & $0,08^{*}$ & 0,17 * & $0,03 *$ & 0 \\
\hline Kedungbanteng & $0,06^{*}$ & $0,02 *$ & 0 & 0 & $0,02 *$ \\
\hline Baturaden & $0,5^{*}$ & $0,02 *$ & 0 & 0 & 0 \\
\hline Kembaran & 0 & 0 & 0 & $0,03^{*}$ & 0 \\
\hline Sokaraja & $0,01 *$ & $0,01 *$ & 0 & 0 & 0,01 * \\
\hline Purwokerto Barat & $0,02 *$ & $0,04 *$ & 0 & 0 & 0 \\
\hline Purwokerto Timur & $0,02^{*}$ & 0 & 0 & 0 & $0,02 *$ \\
\hline Purwokerto Selatan & 0 & 0 & 0 & 0 & 0 \\
\hline Purwokerto Utara & 0 & 0 & 0 & 0 & 0 \\
\hline Pekuncen & 0 & 0 & 0 & 0 & 0 \\
\hline Sumbang & 0 & 0 & 0 & 0 & 0 \\
\hline Purwojati & 0 & 0 & 0 & 0 & 0 \\
\hline
\end{tabular}

\begin{tabular}{ll}
\hline Keterangan & \\
$* * * *$ & $:$ HCI API $>5 / 1000$ penduduk \\
$* *$ & $:$ MCI API $1-5 / 1000$ penduduk \\
$*$ & $:$ LCI API $<1 / 1000$ penduduk \\
& $:$ Non API $0 / 1000$ penduduk
\end{tabular}

Tabel 2. Distribusi Frekuensi API dan Faktor-faktor yang Berhubungan

\begin{tabular}{llcc}
\hline Variabel & Kategori & Jumlah & $\%$ \\
\hline API & LCI-MCI & 36 & 44,4 \\
\multirow{3}{*}{ Curah hujan } & Nonkasus & 45 & 55,6 \\
& Tinggi & 39 & 48,1 \\
Luas wilayah & Sedang-sangat rendah & 42 & 51,9 \\
& Luas & 40 & 49,4 \\
Ketinggian* & Tidak luas & 41 & 50,6 \\
& Sedang & 10 & 37,0 \\
Jumlah pendatang & Rendah & 17 & 63,0 \\
\multirow{2}{*}{ Kepadatan penduduk } & Tinggi & 40 & 49,4 \\
& Rendah & 41 & 50,6 \\
& Tinggi & 18 & 22,2 \\
& Sedang & 39 & 48,1 \\
& Rendah & 24 & 29,7 \\
\hline
\end{tabular}

*Data ketinggian di 27 kecamatan dianggap tidak berubah selama tahun 20112013 
Tabel 3. Hasil Analisis Bivariat Faktor yang Berhubungan dengan API Malaria di Kabupaten Banyumas Tahun 2011-2013

\begin{tabular}{|c|c|c|c|c|c|c|c|c|}
\hline \multirow{3}{*}{ Variabel } & \multirow{3}{*}{ Kategori } & \multicolumn{4}{|c|}{ API } & \multirow{2}{*}{\multicolumn{2}{|c|}{ Total }} & \multirow{3}{*}{ Nilai $p$} \\
\hline & & \multicolumn{2}{|c|}{ LCI-MCI } & \multicolumn{2}{|c|}{ Nonkasus } & & & \\
\hline & & $\mathbf{n}$ & $\%$ & n & $\%$ & $\mathbf{N}$ & $\%$ & \\
\hline \multirow[t]{2}{*}{ Curah hujan } & Tinggi & 14 & 35,9 & 25 & 64,1 & 39 & 100 & 0,205 \\
\hline & Sedang - sangat rendah & 22 & 52,4 & 20 & 47,6 & 42 & 100 & \\
\hline \multirow{2}{*}{ Tempat perindukan } & Luas & 23 & 57,5 & 17 & 42,5 & 40 & 100 & 0,035 \\
\hline & Tidak luas & 13 & 31,7 & 28 & 68,3 & 41 & 100 & \\
\hline \multirow[t]{2}{*}{ Ketinggian* } & Sedang & 3 & 30,0 & 7 & 70,0 & 17 & 100 & 0,629 \\
\hline & Rendah & 7 & 41,2 & 10 & 58,8 & 10 & 100 & \\
\hline \multirow[t]{2}{*}{ Jumlah pendatang } & Tinggi & 13 & 32,5 & 27 & 67,5 & 40 & 100 & 0,045 \\
\hline & Rendah & 23 & 56,1 & 18 & 43,9 & 41 & 100 & \\
\hline \multirow[t]{3}{*}{ Kepadatan penduduk } & Tinggi & 3 & 16,7 & 15 & 83,3 & 18 & 100 & 0,012 \\
\hline & Sedang & 18 & 46,2 & 21 & 53,8 & 39 & 100 & \\
\hline & Rendah & 15 & 62,5 & 9 & 37,5 & 24 & 100 & \\
\hline
\end{tabular}

*Data ketinggian di 27 kecamatan dianggap tidak berubah selama tahun 2011-2013

penelitian oleh Honrado and Fungladda, ${ }^{13}$ rumah yang berada dekat dengan tempat perkembangbiakan nyamuk dapat meningkatkan risiko penularan sebanyak 2,37 kali, sedangkan di daerah hutan yang terjadi penularan aktif risiko penularan akan meningkat 7,19 kali.

Tempat perindukan nyamuk Anopheles biasanya tersebar di sekitar pantai, rawa-rawa, persawahan, ladang, hutan, kawasan berbukit, dan biasanya merupakan tempat-tempat yang cenderung kotor dengan dasar tanah seperti pinggiran sawah dan parit. Kabupaten Banyumas memiliki banyak kecamatan dengan kondisi lingkungan yang mendukung sebagai tempat perindukan nyamuk Anopheles yaitu berupa hutan dengan banyak semak, daerah-daerah berbukit, dan perkebunan di sekitar pemukiman penduduk, terutama pada wilayah yang letaknya jauh dari pusat pemerintahan.

Berdasarkan sebaran kasus malaria selama tahun 2011 - 2013 dapat dilihat bahwa sebagian besar kasus terjadi pada kecamatan yang tergolong masih pedesaan dan berada jauh dari pusat pemerintahan (Purwokerto) sehingga masih banyak ditemukan hutan, pekarangan, maupun ladang di sekitar pemukiman.

Hasil analisis menunjukkan adanya hubungan antara jumlah pendatang dengan API malaria. Berdasarkan data dari Dinas Kesehatan Kabupaten Banyumas tahun 2013, kasus impor di Kabupaten Banyumas lebih banyak terjadi, yaitu sebanyak $52 \%$ dan sisanya sebanyak $48 \%$ merupakan kasus indigenus. Kasus impor yang terjadi di Kabupaten Banyumas disebabkan karena masuknya pendatang ataupun berasal dari warga yang sudah pindah ke daerah endemis kemudian kembali lagi ke kampung halaman. Daerah tersebut seperti Banjarnegara, Wonosobo, Kebumen, Cilacap, ataupun yang berasal dari beda pulau seperti Kalimantan, Sumatera, Riau, dan lain-lain. ${ }^{14}$

Kasus impor akan terjadi di suatu wilayah apabila ter- dapat sumber penular (pendatang dengan Plasmodium dalam darah) dan terdapat vektor penular malaria. Kecamatan yang memiliki kasus malaria di Kabupaten Banyumas, rata-rata memiliki nilai in migrant rate (IMR) yang meningkat dari tahun 2011 sampai 2013. Kecamatan tersebut meliputi kecamatan Lumbir, Kebasen, Kemranjen, Sumpiuh, Tambak, Somagede, Karanglewas, Banyumas, dan Cilongok.

Penelitian ini sesuai dengan penelitian Pim and Lisbeth, ${ }^{15}$ yang membuktikan bahwa adanya pergerakan dari penduduk akan menciptakan faktor risiko untuk terinfeksi malaria. Masuknya pendatang terutama yang berasal dari daerah endemis akan menciptakan masalah dalam usaha mengontrol malaria.

Penelitian lain oleh Pindolia et al, ${ }^{16}$ menyatakan bahwa adanya migrasi penduduk akan berpengaruh terhadap penyebaran malaria pada kasus impor. Migrasi dari wilayah endemis akan membuat terjadinya infeksi malaria yang menyebabkan penularan malaria pada wilayah yang sebenarnya bukan wilayah endemis malaria.

Hasil penelitian menunjukkan adanya hubungan antara kepadatan penduduk dengan API malaria. Hasil penelitian ini sesuai dengan penelitian Tomkins and Ermert, ${ }^{17}$ yang menyatakan bahwa kepadatan penduduk memiliki hubungan yang positif dengan intensitas menggigit dari nyamuk Anopheles. Penelitian lainnya menyebutkan terdapat hubungan antara kepadatan penduduk dengan fluktuasi kesakitan malaria. ${ }^{18}$

Kasus malaria terdapat lebih banyak pada daerah yang kepadatan penduduknya rendah yaitu di daerah perdesaan. Daerah perdesaan di Kabupaten Banyumas merupakan daerah dengan kondisi geografi berupa hutan dan semak-semak, sebagai tempat perindukan nyamuk Anopheles. Sebaran kasus malaria pada daerah dengan kepadatan penduduk yang rendah dimungkinkan terjadi karena pengaruh karakteristik wilayahnya cenderung 
masih banyak ditemukan semak belukar, hutan, perkebunan, dan sawah. Karakteristik tersebut sangat sesuai digunakan sebagai tempat perindukan nyamuk Anopheles yang menyukai daerah yang kotor, banyak semak, dan terdapat banyak genangan air dengan dasar tanah.

Kepadatan penduduk kecamatan di Kabupaten Banyumas sebagian besar masuk dalam kategori kepadatan penduduk sedang $(48,1 \%)$. Kecamatan yang masuk ke dalam kategori tersebut adalah kecamatan yang tergolong masih perdesaan dan berada jauh dari pusat kota seperti Sumpiuh, Tambak, Kemranjen, Somagede, Wangon, Rawalo, Lumbir, dan Cilongok. Berdasarkan analisis bivariat yang telah dilakukan, kecamatan dengan API yang termasuk kategori LCI dan MCI yang memiliki kepadatan penduduk rendah $(62,5 \%)$ empat kali lebih besar dibandingkan dengan kecamatan dengan API yang termasuk kategori LCI dan MCI yang memiliki kepadatan penduduk tinggi $(16,7 \%)$.

Hasil penelitian menunjukkan bahwa tidak terdapat hubungan antara curah hujan dengan API di Kabupaten Banyumas. Hasil penelitian ini berlainan dengan penelitian di Tibet menyatakan bahwa curah hujan sebagai faktor lingkungan yang penting dalam penularan malaria, tetapi pengaruhnya tidak langsung linier. ${ }^{4}$ Pengaruh curah hujan pada penularan malaria dipengaruhi kondisi letak geografis dan perilaku lokal dari nyamuk. Hujan menyediakan keuntungan bagi nyamuk untuk berkembang biak jika jumlahnya cukup, tetapi akan merusak tempat perindukan dan mengeluarkan larva jika jumlahnya berlebihan. ${ }^{19}$ Penelitian di Jimma Ethiopia dan Shucher China menunjukkan total hujan bulanan berhubungan dengan malaria bulanan.6,20 Di Ghana, curah hujan mingguan berhubungan dengan insiden malaria. ${ }^{21}$ Tinggi rendahnya curah hujan akan memengaruhi keberadaan habitat perkembangbiakan vektor malaria. Curah hujan tidak memengaruhi populasi vektor dewasa pada bulan yang sama, tetapi baru akan memengaruhi pada bulan berikutnya sesuai dengan siklus hidup nyamuk di alam. Hasil penelitian di Sukabumi menunjukkan indeks curah hujan berhubungan dengan Man Bitting Rate (MBR) untuk nyamuk Anopheles aconitus dan Anopheles maculatus. ${ }^{22}$ Adanya hujan akan menambah jumlah dan jenis genangan air, yang sebelumnya hanya sedikit atau tidak ada pada musim kemarau.

Penelitian oleh Vanderwal and Paulton menyatakan bahwa curah hujan akan berhubungan dengan kejadian malaria apabila terdapat jeda pada setiap turun hujan sehingga saat genangan air terbentuk nyamuk dapat memulai siklus hidupnya dengan kondisi lingkungan yang mendukung. Hujan deras dan terus menerus dapat merusak tempat perkembangbiakan nyamuk dan menyebabkan turunnya populasi nyamuk. ${ }^{23}$

Hasil penelitian menunjukkan bahwa tingkat curah hujan di Kabupaten Banyumas sebesar 51,9\% masuk ke dalam kategori curah hujan sedang-sangat rendah, dan $48,1 \%$ masuk ke dalam curah hujan tinggi. Meskipun curah hujan sedang-sangat rendah lebih banyak daripada curah hujan tinggi, berdasarkan data untuk kategori curah hujan sedang-sangat rendah lebih banyak didominasi oleh data curah hujan sedang. Hal ini menunjukkan bahwa pada dasarnya kecamatan di Kabupaten Banyumas memiliki tingkat curah hujan yang tinggi dan sedang. Curah hujan yang melimpah atau terlalu deras, dapat menghancurkan telur ataupun larva dari nyamuk Anopheles. Kabupaten Banyumas merupakan wilayah dengan tingkat curah hujan yang tinggi. Rata-rata curah hujan tahun 2011-2013 adalah sebesar 3151,56 mm. Hari hujan tertinggi yaitu dapat mencapai 30 hari hujan. ${ }^{11}$

Tidak adanya hubungan curah hujan dengan API malaria disebabkan karena tingkat curah hujan yang tinggi dan hari hujan yang sering dalam satu bulan, sehingga menyebabkan waktu nyamuk untuk berkembang menjadi berkurang. Penyebab lainnya yaitu titik dari pengambilan curah hujan yang kurang mewakili setiap kecamatan. Data berasal dari stasiun pengamat hujan yang letaknya berada hanya pada satu titik desa, padahal dalam satu kecamatan bisa terdiri dari 9 - 12 desa, selain itu penggunaan data curah hujan tahunan juga dapat menjadi salah satu penyebab tidak berhubungannya curah hujan dengan API.

Hasil analisis menunjukkan tidak adanya hubungan antara ketinggian dengan API malaria. Ketinggian ratarata kecamatan di Kabupaten Banyumas adalah 100,27 mdpl. Kecamatan di Kabupaten Banyumas yang termasuk dalam kategori LCI dan MCI memiliki ketinggian yang rendah $(41,2 \%)$ yaitu antara $0-100 \mathrm{mdpl}$.

Hal ini tidak sesuai dengan pernyataan Raharjo, ${ }^{24}$ yang menyatakan ketinggian optimal bagi nyamuk Anopheles adalah antara 100-130 mdpl. Hasil penelitian justru menunjukkan ditemukannya kasus malaria pada kecamatan dengan ketinggian di bawah 100 mdpl dan di atas $130 \mathrm{mdpl}$.

Penelitian oleh Drakeley et al,25 menyatakan adanya korelasi antara ketinggian dan curah hujan dengan kejadian malaria. Ketinggian dapat digunakan untuk menjelaskan transmisi malaria pada suatu wilayah, hanya saja variabel klimatologi tidak bisa berdiri sendiri untuk menjelaskan kejadian malaria, diperlukan variabel lain seperti spesies dari vektor, topografi, host, sosial-ekonomi, dan lain sebagainya. Tidak berhubungannya ketinggian dengan API malaria disebabkan karena pada penelitian ini hanya variabel ketinggian yang digunakan untuk menjelaskan API malaria tanpa menggunakan variabel lainnya sebagai pendukung.

Penelitian ini mempunyai kelemahan, yaitu variabel curah hujan dan ketinggian tidak berhubungan dengan 
API malaria di Kabupaten Banyumas. Padahal teori dan hasil-hasil penelitian menunjukkan hubungan yang sebaliknya. Hal ini diduga karena kualitas dan validitas penggunaan data sekunder yang digunakan kurang mendukung.

\section{Kesimpulan}

Hasil penelitian menunjukkan faktor yang terbukti berhubungan dengan API di Kabupaten Banyumas adalah luas tempat perindukan, jumlah pendatang, dan kepadatan penduduk. Faktor yang terbukti tidak berhubungan dengan API di Kabupaten Banyumas adalah curah hujan dan ketinggian.

\section{Saran}

Berdasarkan hasil penelitian, disarankan bagi Dinas Kesehatan Kabupaten Banyumas untuk meningkatkan kesadaran masyarakat dalam menjaga kebersihan lingkungan terutama yang berpotensi sebagai tempat perindukan vektor malaria dan peningkatan sistem skrining kepada setiap pendatang yang masuk ke wilayah Kabupaten Banyumas.

\section{Ucapan Terima kasih}

Penelitian ini dilaksanakan melalui skema penelitian Hibah bersaing dengan Nomor Surat Perjanjian 1285/UN23.10/PN/2014 dan dibiayai oleh DIPA Unsoed No.DIPA-023.04.2.189899/2014. Tim penulis mengucapkan terima kasih kepada Lembaga Penelitian dan Pengabdian kepada Masyarakat (LPPM) Universitas Jenderal Soedirman dan tim reviewer yang telah memeriksa naskah kami.

\section{Daftar Pustaka}

1. Badan Penelitian dan Pengembangan Kementerian Kesehatan Republik Indonesia. Riset kesehatan dasar tahun 2013. Jakarta: Kementerian Kesehatan Republik Indonesia; 2013.

2. Harijanto PN. Malaria, epidemiologi, patogenesis, manifestasi klinis dan penanganan. Jakarta: EGC; 2000.

3. Paaijmans KP, Read AF, Thomas MB. Understanding the link between malaria risk and climate. Proc Natl Acad Sci [serial on internet]. 2009 [cited 2014 jan 10]; 106: 13844-49. Available from: http://www.pnas. org/site/aboutpnas/index.xhtml)

4. Huang F, Zhou S, Zhang S, Wang H, Tang L. Temporal correlation analysis between malaria and meteorological factors in Motuo County, Tibet. Malaria Journal [serial on internet]. 2011 [cited 2015 Jan 13]; 10(1): [about 8 p.] Available from:: http://www.malariajournal. com/content/10/1/54.

5. Paaijmans KP, Imbahale SS, Thomas MB, Takken W. 2010. Relevant microclimate for determining the development rate of malaria mosquitoes and possible implications of climate change. Malaria Journal [serial on internet]. 2010 [cited 2015 Jan 15]; 9 (196): [about 8 p.] Available from: http://www.malariajournal.com/content/9/1/196

6. Alemu A, Abebe G, Tsegaye W, Golassa L. Climatic variables and malar- ia transmission dynamics in Jimma town, South West Ethiopia. Parasites \& Vectors [serial on internet]. 2011 [cited 2015 Jan 15]; 7 (1): [about 9 p.], Available from: http://www.parasitesandvectors.com/content/4/1/30.

7. Suwito, Hadi UP, Sigit S. Hubungan iklim, kepadatan nyamuk anopheles dan kejadian penyakit malaria. Jurnal Entomologi Indonesia [internet]. 2010 [diakses tanggal 5 Desember 2013]; 7 (1): 42-53. Diunduh dalam: http://ilkom.journal.ipb.ac.id/index.php/entomologi /article/view/6069.

8. Pinsent A, Read JM, Griffin JT, Smith V, Gething P, Ghani AC, et al. Risk factor for UK Plasmodium falciparum cases. Malaria J [serial on internet]. 2014 [cited 2015 mar 19]; 13 (298): [about 8 p.] Available from: http://www.malariajournal.com/content/13/1/298.

9. Ricotta EE, Frese SA, Choobwe C, Loise TA, Shiff CJ. Evaluating local vegetation cover as a risk factor for malaria transmission: a new analytical approach using image. Malaria J [serial on internet]. 2014 [cited 2015 Jan 15]; 13 (94): [about 7 p.] Available from: http://www.malariajournal.com/content/13/1/94.

10. Dinas Kesehatan Kabupaten Banyumas. Profil kesehatan Kabupaten Banyumas tahun 2013. Purwokerto: Dinas Kesehatan Kabupaten Banyumas; 2013.

11. Badan Pusat Statistik. Kabupaten Banyumas dalam angka 2013. Purwokerto: Badan Pusat Statistik Kabupaten Banyumas; 2013.

12. Ernawati K, Soesilo B, Duarsa A, Rifqatussa'adah. Hubungan faktor resiko individu dan lingkungan rumah dengan malaria di punduh pedada kabupaten pesawaran provinsi lampung. Makara Kesehatan. 2010; 15 (2): 51-7.

13. Honrado ER, Fungleda W. Social and behavioral risk faktors related to malaria in southeast asia countries. Bangkok: Department of Tropical Medicine, Faculty of Tropical Medicine, Mahidol University; 2013.

14. Yani F, Bakoro T. Faktor resiko kejadian malaria dan pemetaan pola sebaran vektor pada desa endemis malaria di Kabupaten Banyumas Provinsi Jawa Tengah Tahun 2012 [tesis]. Yogyakarta: Ilmu Kesehatan Masyarakat Universitas Gadjah Mada; 2013.

15. Pim M, Lisbeth H. Malaria on the move: human population movement and malaria transmission. Journal Emerging Infectious Diseases. 2000; 6:103-9.

16. Pindolia DK, Garcia AJ, Huang Z, Fik T, Smith DL, Tatem AJ. Quantifying cross-border movements and migrations for guiding the strategic planning of malaria control and elimination. Malaria J [serial on internet]. 2014 [cited 2014 Des 5]: 13 (169); [about 11 p.]. Available from: http://www.malariajournal.com/content/13/1/94.

17. Tompkins AM, Ermert V. A regional-scale, high resolution dynamical malaria model that accounts for population density, climate and surface hydrology. Malaria J [serial on internet]. 2013 [cited 2014 Des 5] ; 12(65): [about 24 p]. Available from: http://www.malariajournal. com/content/pdf/1475-2875-12-65.pdf

18. Hakim L, Sugianto. Hubungan kepadatan populasi nyamuk Anopheles sundaicus dengan tempat perkembangbiakan di Kabupaten Ciamis. Jurnal Ekologi Kesehatan. 2009; 8 (2): 964-70.

19. Reiter P. 2001. Climate change and mosquito-borne disease. Environmental Health Perspectives. 2001; 109: 223-34.

20. Bi P. Climatic variables and transmission of malaria?: a 12-year data analysis in Shuchen County, China. Public Health Reports. 2003; 118 
(February): 65-71.

21. Krefis AC, Schwarz NG, Kruger A, Fobil J, Nkrumah B, Acquah S, et al. Modeling the relationship between precipitation and malaria incidence in children from a holoendemic area in Ghana. Am J Trop Med Hyg [serial on internet]. 2011 [cited 2015 Jan 15]; 84 (2): [about 6 p.] Available from: http://www.pubmedcentral.nih.gov/articlerender.fcgi? artid=3029183\& tool=pmcentrez $\&$ rendertype $=$ abstract.

22. Hakim L, Ipa M. Sistem kewaspadaan dini KLB malaria berdasarkan curah hujan, kepadatan vertor, dan kesakitan malaria di Kabupaten Sukabumi. Media Litbang Kesehatan. 2007; 17(2): 34-40.
23. Vanderwal T, Paulton R. Malaria in the limbe river valley of Northern Haiti: a hospital-based retrospective study, 1975-1997. Revista Panamarica de Salud Publica. 2000; 7(3): 162-7.

24. Raharjo M. Studi karakteristik wilayah sebagai determinan penyebaran malaria di lereng barat dan timur Pegunungan Muria Jawa Tengah [tesis]. Yogyakarta: Ilmu Lingkungan UGM; 2003.

25. Drakeley CJ, Carneiro I, Reyburn H, Malima R, Lusingu JPA, Cox J, et al. Altitude dependent and independent variations in Plasmodium falciparum prevalence in Northeastern Tanzania. The Journal of Infectious Diseases. 2005; 191: 1589-98. 